KATALIN SZAMEL *

\title{
Social Europe and Its Hungarian Lessons
}

\begin{abstract}
Europe is not only the land of origin, but also the principal keeper of social rights, since it is associated with the concept of Europeanism. The obvious social restrictions in Hungary as well as in other countries of Europe in recent years make it absolutely reasonable to examine to what social-economic context the discernible withdrawal of welfare services provided by the state is attributable. The similar manifestations are supported by no means by the same system of social conditions. As to its basis and dating back to its historical origin, the current social policy of the EU is framed in the spirit of the conceptual system of the social state. The Fundamental Rights Charter (just as the "European Constitution Treaty", as part of which it may become mandatory) does not reflect either the labour society or Europe of the peoples, but the conceptions of the capital, of political classes and eurocracy. Nevertheless: considering the power relations of global capitalism, we need to appreciate as an apparent actuality that in the midst of these relations the charter insists not only on the requirement of European unity, but also on a modernised version of the social conceptual system. The purpose of this treatise has been to highlight that social objectives cannot be treated as isolated from their economic and social context. We should not risk balance by the maintenance and preservation of a social-organisational framework via overspending, which altogether contradicts the possibility of development and the sustainability of equilibrated development.
\end{abstract}

Keywords: social rights; welfare state; welfare benefit, social state; social policy; social concept; neo-liberal economic policy; administration; Fundamental Rights Charter of the European Union; Lisbon Treaty; active integration; civil society; civil organisations

\section{Introduction}

The obvious social restrictions in Hungary as well as in other countries of Europe in recent years make it absolutely reasonable to examine to what socialeconomic context the discernible withdrawal of welfare services provided by the state is attributable. The similar manifestations are supported by no means

* Professor of Administrative Law, Corvinus University of Budapest, Faculty of Public Administration; Senior Research Fellow, Institute for Legal Studies of the Hungarian Academy of Sciences, H-1014, Budapest, Országház u. 30.

E-mail: szamel@jog.mta.hu

** This paper was written within the framework of the project $\mathrm{N}^{\mathrm{o}}$ NKFPG-00075/2005 on "The effects of European Union's membership on Hungarian law and administration". 
by the same system of social conditions. The cancellation of welfare benefits raises tensions everywhere, however, in post-socialist states this coincides with the fact that in societies which provide welfare benefits at a higher level than they could afford according to the level of economic development, the transition is by far more difficult, since the population had not been in fact prepared to design its life on different bases. In Western Europe, the transition has been somewhat more planned and the role taking of the state and the effect of the European integration have been capable of gradually adjusting social motions to different paths. These societies demonstrate that the peripheral conditions of the responsibility of individuals taken for themselves have evolved, scilicet, these states offer alternatives, real opportunities and individual fates follow coerced paths to a less extent. I think the complex conception which does not regard social expenditure as unproductive cost, but regards it as a heaver of economic growth, which associates welfare benefits with achievements, does really provide greater opportunity for sustenance at an individual and social level equally.

An inquiry into the public administrative context of the issue is equally important. Since on the one hand, it was the establishment of the social duties of the state that entailed a significant extension of the state and administrative duties by taking a new kind of role in the $19^{\text {th }}$ century at the expense that the state abandoned its former non-interference policy with economy, which at the same time swelled its duties to an unpredictable extent. Although, it endeavours to shirk that scope of duties more and more, it is not all as smooth sailing as we imagine, since in the meantime the social consciousness of humankind due to the incorporation of social rights into international documents and domestic law has grown to such an extent that the curtailment of these rights cannot be implemented without a hitch, scilicet, the free spirit cannot be smoothly corked back into the bottle. Nevertheless, public administration is trying to apply new solutions, on the one hand, by transferring its duties to the actors of the civil sector, on the other hand, by making in the same manner the implementation of its social duties more efficient, inexpensive and more reliable.

The social concept has covered a long distance since its evolution. Social rights have had ascendant and descendant eras, ${ }^{1}$ although, they have been in the crossfire of ideological, philosophical and economic-political debates at all times, nevertheless, they have not been relegated or neglected so far, since at times this was attempted, it turned out to arouse fits of social passion, which has often forced the most resolute reformers to recoil.

1 See: A szociális piacgazdaság szociálpolitikájától a neoliberális állam antiszociálpolitikájáig (From the Social Policy of Social Market Economy to the Anti-Social Policy of the Neo-Liberal State). http://www.brainworker.ch/Sozialstaat/sozialpolitik.htm 
We can state that Europe is not only the land of origin, but also the principal keeper of social rights, since it is associated with the concept of Europeanism. (They have turned up outside Europe as a result of waves of constitutionalism.) This, however, does not imply that the enforcement of social rights and social achievements in European states would mean the same. The fact that social rights have manifest bad patches dependant on the economy and politics, has not implied the explicit acknowledgement of the change of the basic ideology set forth under statutes. At the same time, we need to understand that social states have not constructed their systems on the same basis, and in this context some of them on an essentially more solid basis in terms of welfare could reach more considerable achievements, i.e, social security which insures living for all, thereby, they have become exemplary (the Scandinavian wonder). Such diverse starting points seem to be more adequate for the maintenance of social achievements, possibly since social solidarity became more established in public thinking, which renders basic issues, such as everyone has the right to a living at all ages, substantially unquestionable.

When we follow up the changes of the social concept below, we need to inevitably consider the various economic policies, which underlie or support state politics. Economic policies followed by the states objectively substantiate the relation to social rights in economic terms, however, economic efficiency and the relation of the state to social rights are not in direct proportionality. ${ }^{2}$ For the sake of completeness we need to add that its contrary is not positively true: we cannot claim that securing social rights is infallibly anti-achievement, whereas achievement-orientedness would by all means entail social insensitivity. Scilicet, the solution is to be found in their balance. This may require a new way of thinking and essentially, calculations to find out whether a less expensive, but more expedient manner of service obtains instead of the prodigal solutions considered unchangeable. It is also certain that goals need to be reframed, however, we cannot acquiesce without full revision either in adherence to the maintenance of expensive solutions believed (or claimed) to be unchangeable, or in the abandonment of social care. ${ }^{3}$

2 Butterwegge, Ch.: Krise und Zukunft des Sozialstaates. The Crisis and the Future of Social States (Second revised edition). Wiesbaden, 2005, 318.

3 The manner, process and examples of the readjustment of welfare services are analysed in the world-famous work also published in Hungary by Osborne, D.-Gaebler, T.: Új utak a közigazgatásban (Reinventing Government). Budapest, 1994, 330. The fifth chapter deals with achievement-oriented government, which makes it obvious that new objectives and measurable achievements can turn the provision of services more inexpensive and better (consumer friendly). 
What seems to be certain in any case is that the social concept is present in the ideology of the European Union and the effect of the EU prevails and influences the trends of development. This defines a path in post-socialist states, as well, from which any departure is not advisable in the spirit of Europeanism and in the interest of remaining within the EU. Although, in post-socialist states the constrained cancellation of social rights implies something different from that in the EU15, which, however, does not mean at all that it would arouse less tension in these societies, what is more: the change of the basic ideology entails, if possible, greater crises in the lives of individuals as well as in politics.

The social state requires the harmonisation of state action at several levels:

a) The legal framework, within which all the actors of society can proceed, needs to be elaborated at the level of regulation. (E.g., The relations of employers and employees can be settled by the instruments of labour law. These encompass the prohibition of child labour, the issue of labour agreements, the instruments of protection against dismissal, the regulation of working hours. This is merely one area of the pertinent regulation, which needs to be elaborated and implemented in compliance with others.)

b) Social counterbalance is secured by tax policy and the provision of services.

c) The third level consists of financial securities, which provide solutions for elementary life-situations (disability to work, illnesses, retirement, caring and unemployment insurance, basic insurance and welfare benefits for employment seekers, welfare housing constructions, etc.).

d) Finally, this scope includes institutions that promote social integration and socialisation from education to child and youth policy as well as personal services, e.g., in the form of counselling, training and help in threatened life situations.

The state in different societies does not undertake the same role as to the standard of welfare services. The difference consists in the way it interferes with market relations, to what extent it distorts them or facilitates turning the social processes market-oriented, and with respect to these relations, to what extent it endeavours to proceed in a restrictive and redistributive manner. On this basis, I distinguish liberal, conservative and social-democratic basic types.

The state with a social role can have various definitions. In a functional sense, the social state is the complex of state institutions and tax regulations, which can provide solution for crisis situations in a democratic way, remaining in the framework of the social order. These are risks which the market itself cannot handle.

According to the so-called normative definition, the social state implies the extension of state action towards the social. Consequently, the state is capable to decrease social inequalities with legal means. These require the transfor- 
mation of former state action in the spirit of a new social justice, which is possible of course only to a limited extent, since the incorporation of the social concept into the capitalist economic order contradicts the basic concept of capitalism from the outset. ${ }^{4}$

Today, social role-taking by the state essentially overlaps a definite scope of welfare services. Its most important pillars are:

- a comprehensive retirement pension scheme,

- education organised (or supervised) by the state,

- access to healthcare services guaranteed by the state,

- other services accomplished via redistribution and covered by taxes, among these principally the various methods of handling unemployment.

The evolving peripheral conditions of the entire new system attach services to achievements, that is, they integrate more and more conditions into the system, which basically modify the role of the state, decrease and restructure its expenditure, thereby, they base the security of citizens on the market, and on that basis, the state announces social equal opportunity as a basic principle.

\section{Neo-liberal economic policy and social role-taking by the state}

The crisis on the labour market evolving subsequently to the oil crisis in 197475 led to a departure from the demand principle of the Keynes-system and directed the economic policy incurring the change of the state social policy towards an export-oriented supply theory. Afterwards, further establishment of the social state was terminated, although, there was no proof that the management of the social state led to the economic crisis, rather that it could not in fact prevent the crisis and proved an inadequate instrument for the avoidance of crises. ${ }^{5}$

${ }^{4}$ Heimann, E.: Soziale Theorie des Kapitalismus. Theorie der Sozialpolitik (The Social Theory of Capitalism. A Theory of Social Policy). Frankfurt am Main, 1928, 3 (reprinted 1980) 167.

5 This sums up the main argument of the followers of the neo-liberal era of Keynes, nevertheless, they do not see another exit, but the decrease of wages. As Péter Farkas accordingly formulates in his article „Mi jön a monetarizmus után? (A liberalizmus elöretörése a hetvenes évektöl") ["What follows monetarism? (The sudden advance of liberalism since the '70s")], Magyar Tudomány, 45 (2000) 1087. "The experts classified to the trend known as post-keynesianism opened the way towards free market principles. The main representatives are J. Tobin and F. Modigliani. On the one hand, they emphasise more powerfully that "adequate functioning of the market underlies the rational working of the economy", but they also add: "market prices and wages are too stiff to create a socially acceptable balance without adequate state economic policy...". On the other hand, they 
Neoconservative theories and the state policies based on them can be distinguished by the feature that they declare conceptual equality and they are confused enough to motivate the majority, while in fact they commercialize all life-conditions. Becoming a product marks the human condition from birth to death, including studying, free-time activities, love, culture, and so on.

Neo-liberal economic policy increases social differences more and more even in the face of increasing wages. Namely, not only the standard of living rises, but in the face of moderately increasing wages, a price-restucturalisation takes place, which classifies wider and wider strata of the society as hard-up groups and turns even the life of the less poor more and more unendurable in the face of the pressure of consumer society.

It seems that it is not the lack of the budget that is the only reason for the repression of the social achievements of social states, but the world-wide (global) economic competition, from the pressure of which Europe, which professes social principles, cannot withdraw itself, whereas its working seems to become contradictory, while struggling in the net of this duality. The principle of efficiency would require that the socially aided should "get straight" the sooner the better, however, they are often banned from working, while living on unemployment benefit.

The policy supported by a neo-liberal basis represses allowances without performance, whereas, it maintains state social policy in a renewed, modernised form and also extends it with elements that contradict the very neo-liberal economic policy, which eventually manipulates them from the background.

If the states coherently enforced the neo-liberal logic, that would entail that since the expenditure of the social state cannot be afforded, retirement pensions need to be cancelled or curtailed, and there would be no obstacle to the elimination of nursery schools, to raising the retirement age limit, to the elimination of the taxation of the real rich according to their assets, to becoming tax-free of capital returns, to the elimination of the taxation of real estates.

Even if state measures are not so radical, nevertheless, the following tendencies are unfolding in the background:

claim that if disproportionateness is too high, the role of the state should be more powerful, otherwise fine-tuning is sufficient. Contradicting the former leftist interpretators of Keynes, they consider the moderation of wages necessary (in the interest of curbing the inflation and the increase of productivity and production, etc.) Therefore, from an entirely different theoretical basis, they reach the same point as the liberals: the key to the solution of difficulties is the moderation of wages. The experts classified to the trend known as postkeynesianism are open towards free market principles." http://epa.oszk.hu/00700/00775/ 00022/1087-1096.html 
- Endeavours directed at the improvement of the structure of the state budget emerge,

- Expenditure on labour and education is powerfully limited,

- The period of paying unemployment benefits is radically curbed,

- Repressive measures are taken with respect to those living on welfare benefits, the unemployed and refugees,

- Due to the active labour policy of the state, the partial privatisation of the labour market ensues.

Western European societies seem to unanimously follow neo-liberal thought or the implementation of the according sets of measures is just in full swing. At the same time, the reduction of social expenditure is not a sufficient instrument. On the other hand, the increase of revenues should be arranged, which is circumstantial, since the owners of finances can always resort to instruments such as the stoppage of taxes, black market, or "creative" accounting... In fact, a redistribution of revenues takes place, which via the legal decrease of the burdens of enterprises and other forms of amenableness of the state towards them results in an ever increasing difference in income.

Eventually, Agenda 2010 of Europe is also based on the neo-liberal economic policy, even if in form it maintains the legal framework of the social state. From the once social role-taking of the state hardly has been retained more than the formulation of principles, on the basis of which instead of real state services, rights and freedoms are set forth, which at least in principle facilitate, but do not on any account guarantee a living. An ever more significant role devolves on individual efforts and the state promises assistance to these, which in certain cases does not overextend counselling and a control over the sustenance of rights.

Social policy really seems to be a Sisyphean task, since its ultimate goal, i.e., granting equality for all the members of society, has never been achievable. If, however, a certain task is not accomplishable in a certain manner, it is possible that the goals or the manners of implementation or both need to be modified. Nevertheless, we cannot sedate the society with the maintenance of the illusion of both, and not only for ethical reasons, but also because sooner or later the soma will not help the trouble, because a situation can occur, when the inevitable consequence of drug-omission may be the publication of concealed or stretched reality-segments. Therefore, social rights need to be deployed not as a dysfunctional instrument of sedating the people, or as a substitute instrument of arousing remorse, but they need to be regarded as an opportunity, which cannot only be referred to, but which like the gravest social problem can also be treated: wisely and prudently without an ulterior purpose, viewing it as an indispensable instrument of the sustenance of society. 
In this sense, the apparently rightful question remains, if the state, when it facilitates, what is more, supports the becoming market-oriented of social processes, acquiesces in the fact that those without services or vegetating on the periphery of being are doomed to eternal exclusion or intervenes in the interest of balancing the processes by redistribution, which grants opportunity for those in a socially disadvantaged or cumulatively disadvantaged situation. If the state cannot provide that or reduces the responsibility of people for themselves by insuring services, which makes the society forced into overreaching solidarity hostile towards the "parasites", then the state does not perform its real mission, i.e., the maintenance of the balance via securing the sustenance, survival and further development of society. An extravagant diversion by the state in either direction or a resigned detachment is a state policy, which cannot be not undertaken, since we feel pity for discredited politicians, but because non-interference with them means the real danger with respect to our future.

\section{The evolution of the social law of the European Union and its main legal sources}

The regulations of the European Communities have covered a long distance until this day, when the Fundamental Rights Charter, which also encompasses social rights, has gained its ultimate form and may become mandatory.

The basic outlines of the contemporary social policy of the EU are specified in:

- the European Social Charter,

- the Lisbon Treaty,

- the Fundamental Rights Charter of the European Union.

In the beginning, the rules of the European Communities were directed at the elaboration of a uniform regulation with respect to the social sphere. By today, however, this principle seems to have been abandoned. The three essential areas to be harmonised are: overcoming unemployment, improvement of the conditions of existence and of labour, guaranteeing the participation rights of social partners.

The Social Charter sets forth working guidelines for the parties concerned and cannot be regarded as a severe regulation, because it expects the acceded state parties to take the necessary measures dependant on their current economic performance.

Social policy belongs to the scope of tasks, which do not pertain to the effect of Article 3 of the Lisbon Treaty specifying the exclusive authority of the EU, or to the effect of Article 6, which specifies the tasks, with respect to which the EU has authority for the implementation of measures supporting, 
harmonising or supplementing the measures of the member states. These documents, like the documents of the EU generally need to be interpreted in harmony with each other. Nevertheless, the 2007 version of the Fundamental Rights Charter of the EU further specifies the fundamental rights provisions of the Lisbon Treaty, thereby, it may take effect together with the Lisbon Treaty. ${ }^{6}$

The Fundamental Rights Charter is a "formation", which defines the working framework of social provisions, nevertheless, the fact that it was framed has great significance, since it is a modern formulation of subsistence, social security and sustainable life quality, which, although neither detached from the system of economic conditions, nor impassive in a social sense, contains a catalogue of human rights, the enforcement of which it also facilitates.

As to its basis and dating back to its historical origin, the current social policy of the EU is framed in the spirit of the conceptual system of the social state. In spite of that, no meritorious endeavour obtains in the EU for the establishment of a common redistributional social system, whereas, it intends to enforce the most important regulatory elements of social policy on a common basis. The advance of social political systems is restrained by factors, such as the significant differences among the economic development of the member states, which have increased due to the enlargement of the EU. The developed countries of Europe manage extended and expensive social systems despite the gradual rationalisations. Its economic conditions prevail only to a limited extent in newly acceded countries, therefore, although the continually strengthening neo-liberal tendencies (as we intended to demonstrate in the first section) have turned the former social policy, which tried to prescribe definite standards, unfounded, a modified version of the social concept supplemented by several elements is still part of the conceptual system of the European Union. ${ }^{7}$

A new social vision is emerging in the EU concerning how welfare can be most promoted in the midst of the challenges of our age. Opportunities, access and solidarity are placed in the focus of this new approach. This vision reflects the increasingly accepted view that although, society cannot secure equal results for its citizens, we need to endeavour to promote equal opportunity more and more resolutely.

6 The Fundamental Rights Charter of the EU considered as a basis for the analysis here is a revised version of the Charter solemnly proclaimed on 7th December, 2000, which shall supersede the Lisbon Treaty at the time of its taking effect. (See, C 303/14 HU the Official Gazette of the European Union, 14.12.2007.) At the moment its future is uncertain, nevertheless, we think it is necessary to deal with it.

7 Cf., Falusné-Szikra K.: Az EU szociálpolitikája és Magyarország (The Social Policy of the EU and Hungary). Fejlesztés és Finanszirozás, 2004, No 1. 
The Fundamental Rights Charter contains the full scope of civil, political, economic and social rights as the first document in the history of the EU. It draws on the basic treaties and secondary law of the European Union, the Convention and its Protocols, the constitutional traditions of the member states, the adjudication practice of the European Court and the European Court of Human Rights in Strasbourg, the content of the European Social Charter and the Community Charter on the Basic Social Rights of Employees, and on various international treaties and conventions. ${ }^{8}$

The Fundamental Rights Charter (just as the "European Constitution Treaty", as part of which it may become mandatory) does not reflect either the labour society or Europe of the peoples, but the conceptions of the capital, of political classes and eurocracy. ${ }^{9}$ Nevertheless: considering the power relations of global capitalism, we need to appreciate as an apparent actuality that in the midst of these relations the charter insists not only on the requirement of European unity, but also on a modernised version of the social conceptual system.

The essential provisions of the Fundamental Rights Charter with respect to social rights can be found not only in the expressly relevant chapter. It can be discerned that the Fundamental Rights Charter is rather moderate as to social and related rights: it does not declare more than what suits the framework of neo-liberal economic policy without threatening the competitiveness of Europe. Nevertheless, I think that it contains the potential of the social conditions of a broader social policy (interpreted not only as the minimum of living).

\section{The social vision of Europe}

Social challenges and the directions of finding answers in Europe

As we saw, Europe seeks solutions for social problems via new ways and new paths, while it acknowledges that certain problems occur globally and that it cannot withdraw itself from the regularities of certain economic challenges. ${ }^{10}$

${ }^{8}$ E.g., the Conventions of the European Council on Human Rights, Biomedicine and Personal Data, the decisions of the International Criminal Court, the New York Convention on the Rights of the Child, the Convention on the Fight against Corruption, the Treaty on Civil and Political Rights of the UN.

${ }^{C} C f$., Szigeti, P.: Elöre az Európai Unió IV. szociális pillére felé (Ahead towards the Fourth Social Pillar of the European Union). Eszmélet, 2004, No. 64. http://eszmelet. freeweb.hu/ $\& \mathrm{id}=44$

${ }^{10} \mathrm{http}: / /$ www.euroinfo.hu/europaszerver/index2.php?option $=$ com_content\&do_pdf $=1$ 
Owing to these, social processes commenced in the EU, which appeared tendentiously in each state separately, by reason of which confronting them is inevitable.

The most striking fact (as I stated in the introduction) is that social societies have not mastered poverty, what is more, new forms of social exclusion have evolved, against which the fight needs to be taken up in new manners and on a new basis. It is basically important that the society creates opportunity (mainly by investment in human resources) for individuals to sustain their vitality throughout their lives, to stand the test in the midst of challenges, and even advance as far as possible. European states seem to be aware that this does not only require solidarity, but also commitment and investment. The principal goal is basically the extension of life potentials.

It can be generally experienced, which in the future may tendentiously remain unmodified, that in the life of each person several transition periods occur as to employment (such as the transition between school and the workplace, various jobs and positions, job-seeking and training, the interruption of career and the caring period and between active employment and retirement). The danger of polarisation prevails between those who can cope with these difficulties and those who are unable to do so.

Taking cognizance of this, the EU elaborated a system of objectives, which is capable of making the labour market more flexible. The incentives and limitations are adjusted to this and they define the scope for action of employees and enterprises, so that they are made capable of successful adaptation to changes. Security and flexibility can mutually reinforce and complement each other ("flexible security"), thanks to which career starters can start their active life more steeled, where they can get on more easily and remain active for a longer term, since flexible transitions and simply surmountable hindrances are concomitant of their entire career.

The recognition that investment into childhood and youth is crucial as regards the improvement of later prospects is ever more prevalent. This investment is for life (investment into the future). Within this framework, special efforts need to be made in the interest of the development of childcare facilities and of educational institutions for little children, the proper adjustment of school curricula, the reduction of too early school leaving, and the solution of those difficulties that young people need to face on the labour market and with respect to accommodation and finances.

The fundamental change can be recognised that the tendentious endeavour to maintain a "job-for-life", which secures early retirement, is relegated to the background in favour of the view of "capacity for work for life", which provides various strategies for active years in retirement. This is promoted by the more 
easily accessible opportunity for studying for life, flexible working hours, safe and innovative working conditions and the modern and effective mechanisms of social protection. Due to this approach, the number of those increases, for whom work is attractive and whose active life is extended. During this period, they can on the one hand accomplish their life goals, on the other hand, their living is based on more solid grounds in their elderly years and retirement pension is not the only source of it.

The consequences of the aging society are more and more apparent. The new health and social risks have significant consequences as to the systems of social protection. However, demographic change provides new opportunities for the spread of innovative services, products and technologies. For instance, caring for the old as a welfare service can be an essential source of growth and of job creation. From the viewpoint of life cycle, the social and financial consequences of aging necessitate taking responsibility among generations and the thorough consideration of the distribution of related costs among generations.

The active role-taking of women in work and society is still hindered by several obstacles. It implies a risk that caring tasks related to the aging of society devolve on them in an excessive proportion. It is essential that departing from its traditions, (which can by no means be called progressive), the EU abandoned the social and taxation policy based on the "man is the provider" model and shifted to the "two-breadwinning" family model, which allows for individual rights to a greater extent, both members of which can take on jobs and are capable of the proper harmonisation of professional, private and family life. The promotion of this is a task to be supported.

The priorities of the future social policy of the EU consist in the elimination of the differences in salaries between the sexes, the elaboration of taxation systems, which encourage taking on employment, the accomplishment of affordable and accessible forms of caring for children and the old, the establishment of "family-friendly" circumstances, which secure a more flexible order of leave at workplaces during the whole life. At the same time, these measures contribute to the tendency that more employees remain steadily in active life and that the risk of poverty is reduced.

Active integration (in the sense of integration into society) and the enforcement of the prohibition of discrimination demands financial sacrifices from the society, since it is not true, that life-prospects are actually equal in contemporary society.

Actual and equal employment opportunities, the opportunity of studying for life, welfare and health services remarkably differ in the member states of the European Union. A significant part of the population of Europe knows the problems of poverty and social exclusion. It implies serious difficulties for the 
population to create adequate life-conditions and get a job. Since human fates are different, according measures are necessary for the solution of the respective problem. Its precondition is that a sufficient income-subsidising system necessary for warranting lives suitable for human beings obtains, at the same time it needs to be ensured that this system should not be the source of prolonged living, but it should be attached to the opportunity for (entry) or return (in)to the labour market, which can be secured by the promotion of job creation, vocational training and retraining.

Up to 44.6 million persons between the ages 16-64 (that is, 16 p.c. of the population of the EU in active age) claims him/herself to contend with durable health problems or disabilities. Many of them would be willing and able to take on employment, in case adequate circumstances are secured. Although discrimination on grounds of disability, age, religion, race, ethnic origin and sexual orientation is prohibited, they do exist and for many they are detrimental as to life-prospects.

Owing to a lot of various internal and external processes, European societies need to become more open, diverse and complex. The acceptance of diversity, the active integration of those in the most disadvantageous situation, the promotion of equality and the elimination of discrimination are momentous priorities in the EU.

Mobility within the EU belongs to the fundamental rights of citizens, since free movement within the EU is a recognised feature of more integrated economy. More and more people resort to this, if they have the opportunity. Although, Europe reckons with a new wave of migration, which is in a sense necessary for Europe to cope with challenges incurred by the aging and decrease of the population with capacity for work. These waves may be more stirring than traditional waves of migration and the number of people abandoning their homes and then returning there will continually increase. This will result in more open, diverse and complex European societies. For the promotion of an easier integration of migrants, new and prospective approaches are needed, which place the emphasis on mutual respect based on the two-directional process of exercising rights and complying with obligations. Active participation in collective activities such as culture, sports and politics reinforces the coherence and solidarity of European communities, therefore, it is a good instrument of the struggle against the dangers of division and isolation.

Voluntary work and commitment to the civil movement may have prominent roles in the reinforcement of social cohesion. In contemporary Europe, cultural exchange is as lively and vigorous as never before. By reason of the growth of free time, the demand for new cultural products manifests itself more powerfully than ever before. The cultural diversity of Europe is the source of individual 
progress and worldwide spiritual nourishment. At the same time, this has an economic aspect, since innovation and creativity are important driving forces of economic activities and employment in a knowledge-based world.

\section{The role of the European Union}

In several areas of social policy, the different policies of the member states, the diversity of practice and the heterogeneity of national institutions speak against harmonisation. Nevertheless, the purpose of action in the interest of common goals is extraordinarily sweeping. Therefore, in several political areas (such as employment, social inclusion, social protection, education, youth, culture, healthcare and the integration of immigrants) the EU has framed common objectives with different timetables, reporting mechanisms and indexes, which serve monitoring progress and comparing long-standing practices.

The responsibility of member states is noteworthy with respect to taking the necessary political steps so that this vision comes true. The strength of the European Union consists not only in the common scale of values, but also in common action, during which the member states jointly endeavour to achieve results. The reform treaty also contains a horizontal social clause, which highlights the commitment of the EU to employment and social protection and reinforces the role of regions and social partners as part of the political, economic and social arrangement of the EU.

The experiences of the European employment strategy introduced 10 years ago, which also constitutes an essential pillar of the Lisbon strategy, demonstrate that these mechanisms are able to result in positive changes, place those priorities in new light that were formerly not attached prominent significance on an EU-level. These are the issues of "flexible security", the quality and productivity of work, childcare, immigration, illegal employment and of the situation of minorities. These processes undergoing for several years are considered successful, since they have facilitated for member states to determine common objectives. However, they have proved to be less successful as to the encouragement of political efforts necessary for reaching these common goals.

The EU has needed to think it over and to think continuously further how to make these processes more dynamic and how to facilitate in view of traditions that efforts concentrate more on implementation and the diversity of institutions. ${ }^{11}$

\footnotetext{
${ }^{11}$ For instance, the approach based on "common principles" applied in the case of flexible security would be adequate for the promotion of the active integration of persons most distant from the labour market with the most far-reaching respect for national
} 
For the period 2007-2013 up to 75 billion EURO has been assigned to the European Social Fund (hereinafter: ESF), due to which those in active age can obtain new capabilities and enterprises can build up innovative work systems. Besides, upon the initiative of the Committee, the European Globalisation Fund was established to promote the reintegration into the labour-market of workers who are made redundant on account of the transformation of global commercial customs. This fund is a remarkable manifestation of solidarity for those affected detrimentally by the consequences of globalisation. These persons need to be offered actual preventive and active measures, which will help them in adjustment and progress.

The Committee launched a debate concerning the future of the European budget after 2013. It is important that the results of the current consultation on social relations should be integrated into this debate. The EU has an important role as to the definition of key issues, pressing negotiations and securing the political impetus necessary for common European challenges. Such negotiations are promoted by The European Year of Equal Opportunities for All (2007), The European Year of Cross-Cultural Dialogue (2008) and The European Year of Struggle against Poverty and Social Exclusion (2010).

The evolution of consciousness and the analysis of social questions are often hindered by the lack of complete and up-to-date EU-level statistics and indexes. The collection of comparable data is necessary and poses a serious task further on. Nevertheless, these data are indispensable for decision-makers, so that they can provide adequate information for open discussion and assess the social effect of initiatives.

Several foundations and agencies (the European Foundation for the Improvement of Life and Working Conditions, the newly established the European Agency for Fundamental Rights and the European Institution for Equality between the Sexes) promote the information of decision-makers and those concerned. The more regular consultation and the convocation of independent expert bodies (including the experts of countries outside the EU) are good methods for reinforcing scientific bases and enlivening European political debate.

As to its principles, the renewed Social Agenda issued in July, 2008 builds on former experience. ${ }^{12}$ This array of concepts is guided by the principles of

characteristics and member state authorities. Besides, it seems that greater attention has to be paid to securing coherence among various co-ordinational processes (e.g., the Lisbon strategy, the strategy of sustainable development and programming structural bases).

${ }^{12}$ As a source, I used the Europe-server, which is accessible on the following homepage: http://www.eubusiness.com/Social/renewed-social-agenda/ 
solidarity, success and opportunity. Tasks of high priority include the freedom from discrimination, the improvement of the situation of young people and women, the reinforcement of patients' rights and further approaching the school systems in the interest of migration and mobility.

The EU intends to further approach its objectives to reality. An important basis of this is taking those surveys into consideration, which were carried out among the population in the member states and which will be used during negotiations with the member states concerned for the elaboration of sets of action.

The social effects and the effects on employment of the current crisis will in all certainty incur a graver situation, therefore, efforts at all levels need to be expedited in the interest of intervention against unemployment and a fundamental reform of the systems of welfare aid, healthcare and public health.

The rapid growth of unemployment threatens with more unemployed than at any time since World War II, therefore, the EU convened an extraordinary Employment Summit.

With the decline of economy, the rate of the unemployed in the EU27 rose from 8.1 p.c. (February) to 8.3 p.c. (March). At present, there are 20 million unemployed in the EU, which is four million in excess of the datum last year. In the Euro-zone, the rate of unemployment increased from 8.7 p.c. to 8.9 p.c. However, the worst is probably yet to come. According to expectations, the rate of unemployment in the Euro-zone may reach 11.5 p.c. by the end of 2010: such a high rate of unemployment has been unprecedented since World War II.

The subject matter of the Employment Summit held in May, 2009 was remarkably topical: In March, more than 600,000 people lost their jobs in the $\mathrm{EU}$ and in recent months, there have been protests by reason of the social situation in several countries. ${ }^{13}$

According to the speeches delivered at the Summit, companies could consider the reduction of the working hours of employees instead of prompt dismissals. The employees could spend their relieved free time on the acquisition of new capabilities. Some companies in Germany have already introduced this method.

Besides, companies should employ more trainees, which would promote that young people (especially secondary school and college graduates) take a firm stand on the labour market. At the moment, more than 17 p.c. of young people under 25 is unemployed (which is the double of the average rate of unemployment) and according to estimations, this rate in the member states can exceed 30 p.c. in the future. Therefore, education should develop the most sought capabilities.

\footnotetext{
${ }^{13}$ http://ec.europa.eu/news/employment/090507_hu.htm
} 
The launch of several new enterprises should be supported, which could also improve the employment of young people and the unemployed.

The Committee put the most important proposals of the conference on the agenda of the summit of EU leaders in June.

It is impossible to impede that the crisis entailed increasing unemployment, but swift action may promote that less positions were terminated and that millions of people found new and better employment.

The current programs of the European Social Fund support annually 9 million people, merely in 200910.8 billion Euros has been made available in the form of support via the Fund. The Fund is accessible in case of need incurred by the crisis, e.g., for the improvement of the harmonisation of the demand and supply of labour force, for the support of the common initiatives of social partners, for the encouragement of social innovation and employment partnerships and for the reinforcement of state employment services. The simplification of the rules pertaining to ESF will facilitate the prompt raise of advance payments by 1.8 billion Euros. In all cases, when ESF programming needs to be adjusted to needs incurred by the crisis, the Committee will ensure both the change of programs as soon as possible and redistribution from other funds.

\section{Social Europe and its Hungarian lessons}

The review of the social systems, objectives and achievements of the European Union demonstrates that the view that marks the system of objectives of the EU has significance beyond the traditional view of the social state. It is a complex system, the elements of which cannot be selected one by one and seek solution for one or the other independently, because the result can manifest itself only as a co-efficiency of various state actions, which as a complex can result in the social security of citizens. This requires new activity on the part of the state, a "comprehensive" responsibility for the concerns of society, although these concerns should not be settled by the state, but it should activate the employees in public service, demand and promote that everyone should proceed in his/her problem-solving(-handling) role." ${ }^{\prime 4}$ In this role, the state should activate the market and the labour market, the citizens themselves and public administration, as well.

\footnotetext{
${ }^{14}$ von Bandemer, S.-Hilbert, J.: Vom expandierenden zum aktivierenden Staat (From the Expanding to the Activating State). In: Bandemer, S. (et al.) ed.: Handbuch zur Verwaltungsreform (Handbook to the Reform of Public Administration). Opladen, 1998, 29.
} 
I have dealt with the details of that and since I don't intend to repeat myself, let me just refer to:

- The first scope of tasks (activating the market) encompasses the deregulation of the labour market and making it flexible, relieving it from commercial constraints, the taxation of enterprises and profits, the establishment of a minimum wage scheme, the relegation of measures protecting the employees and securing their participation rights into the background.

- The activation of citizens is promoted by driving back the elements of social security, the integration of expectations and obligations into unemployment and support schemes, the stipulation of the requirement of and the demand of training, in a summary, the integration of various elements of taking responsibility for themselves into the system.

- The tasks of public administration encompass securing the conditions of the smooth working of the market, managing the agreement, quality assurance and attestation schemes, and as an essential element, the change of the methods of financing, e.g., attaching it to achievement and making it a matter of bargaining. An according example is the financing method of expert services, in connection with which the wage elements related to social assistance in line with the related costs and overhead expenses are chargeable. A further example is the settlement of accounts according to social fields, which offers various financing according to various areas of social assistance.

It would be worth studying these forms in details, which, however, would depart from the more theoretical research included in the present study. Nevertheless, we can discern that these working and financing forms of public administration are totally dissimilar to the social working of Hungarian public administration, which works basically as a state distribution system and still does not lack the character of an authority.

Considering the whole period following the change of regime, the greatest trouble is that the social (basically arising as state) expenditure "inherited" from the socialist (Kadarean) regime could not be radically curbed or reduced more extensively by the addition of co-financing elements. The most significant question prevailing until our days has been that after the termination of the rules of obligatory employment under the socialist regime, how the living of those becoming unemployed or generally, how the social security of the members of society can be secured.

Concerning this, noteworthy debates take place not only in the society, but also on the scene of politics, but it was necessary to clarify legally how far the effect of the Constitution and social law ranges. In this respect, the Constitution and the Constitutional Court held from the outset that the rights granted in the former social formation cannot be upheld unchanged, since they are not 
unlimited. In the adjudication practice of the Constitutional Court, the right to services and provision necessary for a living was construed as the minimum of constitutionality. This guarantees the right to human dignity which is a basic requirement. Besides the establishment of institutions, social rights are enforced via the civic rights, nevertheless, no constitutional norm exists with respect to their expanse.

In view of the bearing capacity of the national economy and the condition of the budget, the task of the state is to define the breadth of services considering that the extent of welfare services cannot fall short of the minimum level prescribed under Article 70/E of the Constitution. The abstract quality requirement of the constitutional minimum of the right to services constitutes exactly the realisation of the right to human dignity via securing a living. ${ }^{15}$

A well-known sociologist ${ }^{16}$ concerned with this subject matter is trying to find an answer to the question what the reasons for the fact are that Hungarian public administration has not undergone the decisive contentual-formal change affecting its working, which should have been accomplished so that it became adequate for performing its role directed at the maintenance of social balance under the current social conditions. One of her principal arguments is that the process of denationalisation (desetetisation) has not undergone, what is more, in a sense the old socialist-statist methods could survive under circumstances, the political conditions of which have ceased to prevail. The author emphasises that the structural change has not even entailed the fundamental change of the organisational system, the working methods can be considered totally conservative and in comparison with European solution methods regarded as modern, they are by all means obsolete. One of the obvious reasons for this is that cooperation with the society has not evolved yet, thereby, the only decisive element of the renewal of the system is the working of the parties, which have isolated themselves to a great extent. That is, Hungarian reality is characterised by the prevalence of party interests, aloofness from the civil sphere and the will to formally comply with the European system of expectations and requirements.

Legal special literature has mostly dealt with this issue, when it assessed the activity of the Constitutional Court, and chronologically, when Hungary ratified the European Social Charter.

${ }^{15}$ Holló A.-Balogh Zs. (eds.): Az értelmezett Alkotmány (The Construed Constitution). Budapest, 2000, 706-709. See especially, Decision no. 32/1998, (VI.b25.) AB, which substantiates the disposition of the Constitutional Court.

${ }^{16}$ Szalai J.: Nincs két ország...? Társadalmi küzdelmek az állami (túl)elosztásért a rendszerváltás utáni Magyarországon (Aren’t There Two Countries...? Social Struggles for State (Over)Distribution in Hungary after the Change of Regime). Budapest, 2007, 63-90. 
The formulation of social law equalled a reform from the point of view of public administration, which has retained its basic structure, that is, the manifestation of tasks on multiple levels and their distribution among state administrative and self-governmental organs. The formation of the system of social security into self-governments had been a momentous, but inert attempt, which was followed by renationalisation after a short time. The establishment of job-creation subsidies as an instrument of active intervention can be considered to be in compliance with the European model, which, however, has not entailed a significant and permanent decrease of the unemployment rate.

The reform of healthcare has been a matter of debate for a long time. In spite of the fact that each government since the change of regime put the respective reform on the agenda, and eventually, the legal peripheral conditions of both privatisation and of supplementary insurance evolved gradually, until this day (2008), all attempts at the reduction of the number of hospital beds failed by reason of the resistance of society, primarily of the society of physicians. The outcome of the present reform (the privatisation or pluralisation of health insurance funds) as to its social effects is for the time being unknown, although, we are aware that it has not been received favourably by all the population. In this area, we can also establish that the population acknowledges that reforms are necessary in the interest of the sustainment of the balance of society and the budget, nevertheless, it does not commit itself either to the conceptions of government or of the opposition. ${ }^{17}$

The reform of the retirement pension had been launched earlier, nevertheless, by 2007 the private pension funds proved to be incapable of guaranteeing such an efficiency with respect to securing a solid living for citizens as the (distributional and imposing) pension scheme guaranteed by the state used to. This attempt did not mean more than a set of measures coerced by the state, which (or the manner of the implementation of which) didn't prove really viable. On the basis of the models rendered by European countries, more differentiated methods are necessary.

According to my judgement, the main cause of the failure (in almost all cases) consists in the fact that reform measures are supported by state guarantees, which totally contradicts the rationality of the measures,${ }^{18}$ since it

${ }^{17} C f$., Vásárhelyi, M.: Ki nevet a végén? Reformfília és reformfóbia. In: Schlett I. (ed.): Merre tovább Magyarország? (Who Laughs When the Game Is Over? Reformphilia and Phobia. In: Which Way to Go on, Hungary?), Budapest, 2008. 376-426.

${ }^{18}$ This is valid in the case of retirement pensions as well as of tuition fee loans. The system has become market-based, which is favourable, nevertheless, it contains too many 
relieves those concerned from the burden of risk and responsibility, the most important element of the enterprise, whereas it guarantees profits. Apparently, measures have been gradually taken for the prevention of early, advanced and disability retirement, which can be considered to be rather administrative than a solution bearing social content in the spirit of the EU.

Even if briefly, but we cannot fail to mention the reform of education, which is again permanent. For twenty years, denationalisation as a slogan prevails as to public administration, which in fact means that while the state has formally shirked its obligations as a maintainer, has actually abandoned its institutions in the spirit of autonomy. While Europe endeavours to renew education as to its content, form, quality and efficiency, Hungary is still distant from the enforcement of such endeavours in its system, and instead of the application of incentives, sometimes it employs expressly direct instruments of direction. It has been proved several times that frugality on the part of the state in this area has given rise to lavishness on the part of the institutions, not to mention that it creates little opportunity for real development for the institutions grappling with budget confinements.

Apparently, measures have been taken for the solution of specific areas of equal opportunity. These, according to a time-honoured Hungarian method, have obtained organisational framework, thereby, they can be reckoned up towards the EU as achievements, but for the time being, their real social effect cannot be discerned.

Furthermore, Hungary has also taken measures to simplify the foundation of enterprises by the establishment of a one counter settlement in public administration, however, anyone who tried their working knows that it can by no means called perfect.

In one of his treatises, Elemér Hankiss enumerates all the causes that special literature has pieced together as the causes of the failure of the change of regime. ${ }^{19}$

Almost all the authors mention the absence of real democratic traditions, ${ }^{20}$ when analysing Hungarian circumstances. One of its most eloquent testimonies is that civil organisations working as the principal revisers of public administra-

social elements to substantiate the responsibility of citizens for themselves, which is the basis of the conceptions of the EU.

${ }^{19} C f$., Hankiss, E.: Átmenet - megújulás - regresszió. In: Schlett (ed.): Merre tovább Magyarország? op. cit. 112-188. In this treatise, Elemér Hankiss analyses the contradictions of the peaceful revolution and analyses the situation that has evolved politically and economically in Hungary as the failure of the imagined democratic establishment.

${ }^{20}$ Almond, G. A.-Powell, G. Bingham J.-Strom, K.-Dalton, R. J.: Összehasonlitó politológia (Comparative Political Science). Third revised edition, Budapest, 2006, 83. 
tion cannot make their voice properly heard. Although, on a philosophical and factual compromise-making level these would have significance, not to mention that they would have tasks taken over from public administration (not only on grounds of state aid).

During the recent 10-15 years, the institutions of the EU have demonstrated continually growing interest in the dialogue with civil society, on an EU level, as well.

The participation of civil society has modest traditions in current Hungarian society, although, the respective special literature opens up new prospects to competent participation in the social sphere, as well. ${ }^{21}$ This is most eloquently proved by the fact that it has become a program in the Hungarian Ministry of Social Affairs, maybe as an effect of the EU. The program, however, formulates the actual opportunities for participation more narrowly than it is possible, when in decision-making it focuses on participation in law-making, whereas, in the EU essentially more is facilitated legally. ${ }^{22}$

A treatise on the internet analysing the civil sphere ${ }^{23}$ demonstrates that while the number of civil organisations has considerably risen, out of these only few work in the social sphere. Their relations with public administration are marked by the fact that the organisations that are members of the Economic and Social Council have the most opportunities.

Science makes valuable statements as to the subject of the failure of the "welfare change of regime", when it draws the attention to the errors of the prevailing government and to the dangers which refer to overspending by the state and which shift that overspending on to the future instead of directing the processes within a real framework.

A treatise on the problematic issues of the accession of Hungary to the EU (which is only one of the many) formulates the problem of the steady deficit of the state budget as one of the most worrying concerns of the accession, which as a phenomenon has been prevalent in all of the newly acceded states.

${ }^{21}$ Kiss, Cs.: Az Aarhusi Egyezmény kiterjesztésének jelentösége - A felelelös részvétel elve (The Significance of the Extension of the Aarhus Convention-The Principle of Responsible Participation) [Non-Profit Sector Analysis. Studies on the Exercise of Participational Democracy, see, http://www.nosza.hu/kiss.dbk.pdf]

${ }^{22}$ The Action Plan is accessible on the internet: http://www.szmm.gov.hu/main.php? folderID $=16437 \&$ articleID $=32285 \& \mathrm{ctag}=$ articlelist\&iid $=1$

${ }^{23}$ Kuti, É. (ed.): A magyarországi civil társadalom és a nonprofit szektor helyzete, uniós kapcsolatai, fejlödési irányai (The Situation, EU Relations and Directions of Development of the Civil Society and the Non-Profit Sector in Hungary). Expert Opinion Budapest, 2008. (Version under harmonisation, the study is a property of the Economic and Social Council.) http://www.mgszt.hu/index.php?option=com_docman\&task=cat_view\&gid=19\&Itemid=17 
The deficit of the state budget does not emerge as concomitant of the fluctuations of economy, but it is a basic structural deficiency of the post-socialist state, which derives mostly from social overspending by the state. Restrictive economic policy is not an adequate instrument for the elimination of that, because the only possible solution can derive from increasing incomes, which could substantiate the decrease of the deficit of the state budget and the coverage of social expenditure. ${ }^{24}$

The inherent truth of these statements is by all means justified by the graph, which shows the extremely high rate of social expenditure in a comparison of the European Union. ${ }^{25}$

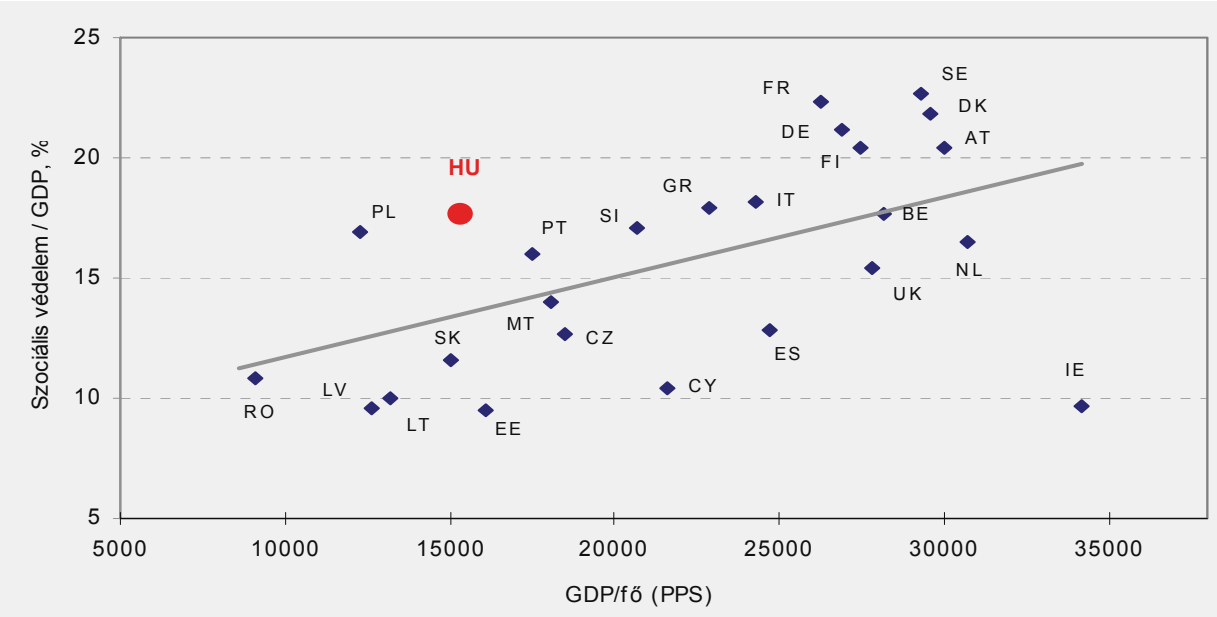

Forrás:Eurostat-COFOG, 2006 (Szlovákia, Románia, Franciaország, Belgium: 2005)

A kiugróan magas GDP/fő mutató miatt Luxemburg nem szerepel az ábrán.

Chart 1. Social expenditures as per cent of GDP and GDP per capita

The graph clearly demonstrates that in comparison with our economic development, the rate of social protection expenditure in comparison with the GDP is above the average.

${ }^{24} C f$., Körösi, I.: Magyarország útja az Európai Unióba - Kompország a nyugati parton (The Path of Hungary to the European Union - A Cruising State on the Western Shore). In: Kiss J. L. (ed.): A huszonötök Európája (The EU25). Budapest, 2005, 786-787.

${ }^{25}$ Source: Hungarian State Budget and Social Expenditure: A European Comparison. www.tarki.hu/hu/news/2008/kitekint/20080610_almos.ppt 
András Sajó in his excellent, but staggeringly sceptical study titled "The Social Reproduction of the Troubles of the Working of the State" states the following:" "As to welfare services, the state has irretrievably intertwined with the society, the political and economic actors and as a captive of this intertwining, with the system providing welfare services, which is less and less maintainable. The troubles of the working of the state are entailed by this intertwining. Party policy dependencies reinforce the reproduction of state dependencies. The system of state organisation is incapable of more rational achievements not only by reason of the over-politicised and anti-initiative nature of its organisations, but because instead of reforms, the enforcement of the self-interest of quasi feudal organisations takes place. By reason of the size of the country, the evolved intertwinings do not facilitate the evolution or working of critical expertise. The massive violation of state norms by the society and authorities is a part of the working of the state and not simply a contingent consequence. It is connected with the infringement of the norms and the institutionalisation of irresponsibility prevailing in the scope of state organs without any consequence."

However, that is not the only reason of overspending by the state. It entails a far greater problem that the growth of state expenditure was not attached to actual economic and social reforms in a manner it should have taken place according to the logic of the European Union. Even if we strip all political overtones from the statements that criticise the economic policy of the Gyurcsány government, it is appalling that all the elements of this economic policy work dysfunctionally, and in fact instead of creating a balance, it attempted to solve urgent troubles by skidded state salaries, while in fact it did not change the structural problems of economy. ${ }^{27}$

The inclusion of those with proper insight into decision-making processes and the establishment of the guarantees of the solidity and the stableness of institutions would be indispensable, which in themselves could ground the recuperation of confidence in the state. ${ }^{28}$

${ }^{26}$ Sajó A.: A társadalom működési zavarai és az államgépezet (Social Malfunction and the machinery of government). Állam-és Jogtudomány, 49 (2008) 3, 233.

${ }^{27}$ Cf., Gazsó, T.-Stumpf, I. (eds.): A jóléti rendszerváltás csődje. A Gyurcsány-kormány első éve. (The Failure of the Welfare Change of Regime. The First Year of the Gyurcsány Government). Budapest, 2005, 745. See, the chapter titled "The Main Directions of Economic Policy" 45-65. The same holds true for employment policy, which instead of improvement entailed further unemployment and thereby further increased social overspending.

${ }^{28}$ Maybe we don't need to prove that the organisational structure of public administration is unfortunately (several times superfluously) under continuous reorganisation, just to 
Today, research concerning expressly public administration convincingly proves that public administration can be neither efficient, nor law-abiding, since its controlling and fining activity, that is, the applied sanctions are not preventive, since they encourage people not to comply with, but to circumvent the law. ${ }^{29}$ This justifies that encouragement might be a better instrument than punishment, but the fixations of social conscience by all means contradict this. Of course, this is only one factor of the efficiency of public administration, since as we saw, it should undergo a fundamental change in its working, so that it could comply with new expectations. Not only the objectives should be properly defined, but the paths towards them should be found within a legal framework.

The purpose of this treatise has been to highlight that social objectives cannot be treated as isolated from their economic and social context. We must not acquiesce in the fact that the main function of public administration, i.e., the maintenance of the balance of society requires more than efficiency in economic terms. But: more and not less! We should not risk balance by the maintenance and preservation of a social-organisational framework via overspending, which altogether contradicts the possibility of development and the sustainability of equilibrated development.

quote one example, how many times the organ keeping in touch with the civil sphere has changed hands during the recent 10 years.

The first "Department of Civil Relations" was established in the Prime Minister's Office and was subject to the supervision of the minister of chancellery. This situation prevailed for a relatively long time. The first change supervened in 2003, when civil matters fell under the supervision of the minister without a portfolio responsible for equal opportunities. The organisational unit in this era was named the Directorate of Civil Relations, but after a short time it was rearranged as a major department subject to the supervision of the Ministry of Youth, Family and Social Affairs and of Equal Opportunities. In 2006, a new change supervened. The department in charge of the civil strategy of government and of the maintenance of civil relations was transferred to the Ministry of Social Affairs and Labour, but this time not as an autonomous major department, but as a department with a rather low number of staff.

${ }^{29}$ Gajduschek, Gy.: Rendnek lenni kellene... (Tények, elemzések a közigazgatás ellenörzési és birságolási tevékenységéröl) [There Should Be Order ... (Facts and Analyses on the Controlling and Fining Activity of Public Administration)]. Budapest, 2008, 399. 